\title{
Necessity of Having Propaedeutic Courses of Computer Science in Preschool and Primary Education in the Republic of Kazakhstan
}

\author{
Yessen Iklasovich Bidaibekov ${ }^{1}$, Lyazzat Baltabaevna Rakhimzhanova ${ }^{1, *}$, Darazha Nagashbaevna Issabayeva ${ }^{1}$, \\ Shekerbekova Shirinkyz Tileubergenovna ${ }^{1}$, Issabayeva Sulu Nagashbaevna ${ }^{2}$, Ainagul Kaipbayeva ${ }^{2}$ \\ ${ }^{1}$ Kazakh National Pedagogical University named after Abai, Kazakhstan, Almaty \\ ${ }^{2}$ Kazakh State Women's Teacher Training University Kazakhstan, Almaty \\ *Corresponding author: lazatr@mail.ru
}

Received May 19, 2014; Revised June 05, 2014; Accepted June 26, 2014

\begin{abstract}
In the article elements of informatization of preschool and primary education at schools of the Republic of Kazakhstan, considering development of system of technical, program, methodical means, providing an introduction of computer science and computing in practice of training and educational process of propaedeutic course of computer science with wide usage of computerized intersubject connections in all school subjects in native Kazakh language are considered. On the one hand, the results will be rely on solution of problems of preschool education system in senior and preparatory groups of preschool institutions of the RK - kindergartens; on the other hand, - on organic interface of propaedeutic school course with basic course of computer science, including program and methodical systems in 5-th-9-th grades and with preprofessional school course of computer science. Besides, perspectives of usage of electronic educational resources in management of all three training levels - propaedeutic, basic and preprofessional will be taken into consideration.
\end{abstract}

Keywords: prepaedeutic course of computer science, computer science in preschool age, computer science in primary school

Cite This Article: Yessen Iklasovich Bidaibekov, Lyazzat Baltabaevna Rakhimzhanova, Darazha Nagashbaevna Issabayeva, Shyryn Tileuberdievna Shekerbekova, Issabayeva Sulu Nagashbaevna, and Ainagul Kaipbayeva, "Necessity of Having Propaedeutic Courses of Computer Science in Preschool and Primary Education in the Republic of Kazakhstan.” American Journal of Educational Research, vol. 2, no. 7 (2014): $472-$ 473. doi: 10.12691/education-2-7-6.

\section{Introduction}

Opportunities for development of pupils' personal potential, critical thinking and their independent activity are provided with implementation by information and communication technologies (ICT) in training process. Corresponding fundamental knowledge, skills in ICT can be and must be formed in preschool and primary education. Thus, the role of early training of computer science and ICT increases.

In Kazakhstan methodical aspects of the early training of computer science are investigated in works of E.Y.Bidaibekov, A.I.Abisheva (methodical aspects of training of pupils in computer science first two years of primary school) [1], D.Baigozhanova (course of computer science for primary school pupils on the basis of intersubject connections), E.Biushkova (training in two lines - algorithmic and user), D.Issabayeva (formation of cognitive interests of younger pupils with help of ICT) [2], E.K.Balafanov, S.T.Mukhambetzhanova and others (work-book "Basis of informational culture" for 1-4 grades).
But, despite the existence of scientific researches of the Republic of Kazakhstan in this sphere, till present time enough system approach to early training of pupils of preschool and primary education in computer science and ICT was not implemented, i.e. it is necessary to enter propaedeutic course of computer science into training process in preschool institutions and primary classes.

The main part of. In N. Nazarbayev's message to the people of Kazakhstan (on January 17, 2014) it is said that «... All developed countries have unique qualitative educational systems... It is planned to provide 100 percent coverage Kazakhstan children from 3 to 6 with preschool education by 2020. In the secondary education it is necessary to screw up comprehensive schools to teaching level in N.Nazarbayev - Intellectual schools... Mastering by pupils skills of critical thinking, independent search and the deep analysis of information has to become the result of their training ...» [3]. It is naturally, that opportunities for development of pupils' personal potential, critical thinking and their independent activity are provided with implementation in educational process by the information and communication technologies (ICT). The corresponding fundamental knowledge, ICT skills can and have to be formed in preschool and primary education. 
That is why, the role of early training in Computer Science and ICT increases.

There are a lot of examples of success usage of information technologies in education in world practice, also acting programmes and projects for maintaining computer science in preschool and primary education. ICT are widely used in preschool and primary education of 5-8 ages children (S. Papert $[4,5,6]$ in the USA, Marsyal Vive in France, E. and B.Sendovs in Bulgaria, A.P.Ershov, Y.A.Pervin [7] in Russia, and in other countries G.M.Kleiman [8], R. Jones [9], R.Gerland [10]).

Any training course has to possess internal unity which is displayed in content and training methods at all training steps. The structure of the course, its basic content lines, in particular, has to provide this integrity [11].

That is why it is supposed that content lines of computer science in preschool and primary education correspond to the content lines in main school, but they are implemented at propaedeutic level. After finishing the education the pupils have to demonstrate formed skills in deal with information and apply them in practical and daily life.

It is possible to consider computer science in preschool and primary education, in particular, in two aspects. The first - from position of formation integrated and system picture about information world, about collectivity of informational processes in wildlife, society, techniques. From this point at propaedeutic level of training pupils must receive necessary elementary idea of informational human activities. The second aspect of propaedeutic course of computer science - methods and means of receiving, processing, transferring, storing and using of information, solution of tasks with help of computer and other means of ICT. In this regard there is a need to build multilevel structure and the content of "Computer Science" in preschool and primary education, with corresponding program and methodical aspects and electronic and educational recourses in state language with national realities.

At the first level of experiment along with questioning, primary school teachers, educators of kindergartens and parents of Kazakhstan quizzed with help of online questioning. At the level of stating experiment examination of knowledge and working skills of preschool and primary school pupils with informational technologies are carried out. Tracking the research results was carried out by analysis and comparison methods. More than 120 educators of kindergartens and 256 primary school teachers participated in the experiments.

\section{Conclusion}

The results of the experiment showed that in the process of passing the program of information technologies in computer science course, a number of pupils, using information technologies for training of other subjects are being increased. Besides, computer science teacher has an opportunity to expand range of used forms of performance of homework's by pupils.

But computer science as a discipline has not found its place in system of discipline in primary school and in preschool institutions yet, beside the need of introduction it in preschool and primary education. School teachers and educators of kindergartens do not have standard program and methodic of training of propaedeutic course of computer science of preschool and primary classes pupils and each of them independently decide, for what and how to teach.

More than $71 \%$ of educators of kindergartens and $76 \%$ of primary school teachers support usage of information technologies and training of computer science in preschool and primary education.

Output. Despite the existence of scientific researches of the Republic of Kazakhstan in this sphere, till present time enough system approach to early training of pupils of preschool and primary education in computer science and ICT was not implemented, i.e. it is necessary to enter propaedeutic course of computer science into training process in preschool institutions and primary classes with program and methodical support of the course.

The research results can be used in lectures for teachers and students of pedagogical universities as a base for further researches in training problems of computer science in preschool and primary education.

\section{References}

[1] Bidaibekov, Y.E. and A.B. Ibasheva, 2012. State and perspective of computer science development in primary classes of schools in the Republic of Kazakhstan.Proceedings of big Moscow workshop in methodic of early training of computer science (issue T.3), Edit. Professors I.V.Sokolova, Y.A.Pervin., pp: 120-125.

[2] Issabayeva, D.N, 2008. Methodic of organization integrate lessons with help of information and communication technologies in primary school. Almaty: Press Dayr, pp: 47.

[3] Decree of the President of the Kazakhstan's Way - 2050: The overarching goal, common interests, common future. "N. Nazarbayev's message to the people of Kazakhstan” of January 17, 2014.

[4] Papert, S, 1989.Revolution in consciousness: Children, Computers and fruitful ideas. Moscow: Pedagogy, pp: 105.

[5] Papert, S, 1992. The Children's Machine: Rethinking School in the Age of the Computer. Moscow: Pedagogy, pp: 250.

[6] Papert, S, 1996. The Connected Family: Bridging the Digital Generation Gap. Moscow: Worl, pp: 261.

[7] Pervin, Y.A, 2008. Methodic of early training of computer science. Moscow: Pedagogy, pp: 180.

[8] Kleiman, G.M., M.M. Humphrey and P.H. Lindsay, 1981. Microcomputers and Huperaktive Children. Creative Computing (issue 1), March: 93-94.

[9] Jones, R., 1984. Micros in the Primary Classroom. L, pp: 104.

[10] GerlandLewels, R., 1982. Microcomputers and Children in the Primary School. L, pp: 225.

[11] Rakhimzhanova, L.B. and Z.Saydinova, 2011. Some questionsof representation models and objects in the propaedeutic course. Information and communication technologies in adult education (issue 1). pp: 49-52. 